\title{
Creating A More Beautiful World: A Century of Progress in the Breeding of Floral and Nursery Plants
}

\author{
Richard Craig \\ The Pennsylvania State University, University Park, PA 16802
}

\begin{abstract}
In an intriguing article titled "Horticulture: the Font for the Baptism of Genetics" by Robert C. Olby (2000) suggests that the establishment of genetics as an experimental science should be credited to the Evolution Committee of the Royal Horticultural Society (RHS). William Bateson was a member of this committee and he was the stimulus for the adoption of Mendelism as a science and for the acceptance of hybridization as a breeding protocol. Olby mentions that the RHS sponsored international meetings on plant hybridization in 1899, 1902, and 1906. It was at the third meeting that William Bateson named Mendel's science genetics. Olby reminds us that hybridization of Fuchsia was the subject of one of Mendel's portraits. Today the RHS is known for its stewardship of the knowledge and practice of horticulture and in particular of ornamental plants. In contrast, Olby states that most prominent biologists of the time, botanists and zoologists, did not accept Mendelism until the early 1920 s.
\end{abstract}

\section{PROLOGUE TO THE 20TH CENTURY}

The world of genetics and breeding was inalterably changed by the experiments of Gregor Johann Mendel. Mendel lived in a world where biology was making great advances. Rudolf Jacob Camerer, also known as Camererius, director of the Botanic Garden and professor of Medicine at Tübingen, Germany, published his letter "De Sexu Plantarum Epistola" that described sex in plants in 1694 (Cook, 1937). In 1717, Thomas Fairchild, in England, reported the first artificial hybrid between the carnation (Dianthus) and sweet william (Caryophyllaceae) (Cook, 1937). From 1761-66, Joseph Gottlieb Koelreuter reported the results of 136 plant hybridization experiments. In his research he noted the uniformity of the F1 hybrid and variability of the F2 generations; his work established plant breeding as a scientific pursuit. He is credited with producing the first experimental hybrid, a cross between two Nicotiana species. Eleven references to his publications are included in Warner et al., 1934.

Andre de Vilmorin, in the early 1800s, developed the principles of pedigree breeding, where individual offspring are observed; however, Mendel did not know of Vilmorin's research. Observation of individuals is what allowed Mendel to develop his laws. Conversely it was a pivotal point in the long battle between evolutionists and Mendelists. Today the name Vilmorin is associated with an active seed business located along the Seine in Paris that has existed since 1727 (Cook, 1937). Quetelets had developed the Theory of Probability in 1846; this development had a profound effect on Mendel's treatment of his data and his development of genetic concepts. Charles Darwin published his Origin of Species in 1859; it was already in its sixth edition by 1872. Darwin coined the term Pangenesis, from which pangene and pangenetic were derived. Pangenesis stated that the germinal material was derived from all parts of the body. This hypothesis was popular for over 2300 years. (Darwin, 1859)

Mendel's life (1822-1884) and research is elucidated by Hugo Iltis (1932) and by some more recent biographers. Experiments in Plant Hybridisation was reported and published in 1866 (Mendel, 1866). His life and research have been examined and reexamined, praised and criticized, adopted and challenged by many scientists and nonscientists alike.

Several authors including Babcock and Clausen (1927), Roberts

J. Franklin Styer Professor Emeritus of Horticultural Botany, The Pennsylvania State University, University Park, Pa.

I acknowledge the technical assistance of Tim Alderton, Lynn Butler, Paul Scanlon and Sarah Smith. I acknowledge Majid Foolad, Richard Grazzini, Robert Griesbach, Nona Wolfram-Koivula, David Lemon, Marietta Loehrlein, and Michael Uchneat for their reviews of this manuscript.
(1929), Zirkle (1935) and Cook (1937) have published books or articles on the early history of genetics and plant breeding. Bibliographies are included in these publications and also in Warner et al. (1934). I will summarize some highlights from their work rather than provide specific citations. Great progress was occurring in the biological sciences in 1866. Haeckel predicted that the cell nucleus would play a role in heredity. Mitosis or somatic cell division was discovered and fully elucidated by A. Schneider in 1873, Butschli in 1875, and Fleming in 1879-81. Hertwig conclusively described fertilization in 1875. Meiosis was described in 1883 by van Beneden and more fully by Boveri and by Ruckert. Strawburger first observed chromosomes in 1875 and the term chromosome was coined by Waldeyer in 1888 . Thus by the 1890 s, science and scientists had evolved an understanding of reproductive biology. With respect to genetics, the prominent school of thought was the population model or pangenesis of Darwin and Galton and Nägeli. Others began work similar to Mendel's in the last years of the 19th century.

\section{THE 20TH CENTURY}

In 1900, three scientists are given credit with discovering Mendel's paper: deVries in France, Correns in Germany and Tschermak, and a Viennese botanist. Some authors use the term rediscoverer rather than discoverer for these scientists. Iltis (1932) indicates that a number of scientists noted Mendel's paper before 1900 but that none of them understood his laws of heredity. There is anecdotal evidence that a Russian graduate student recognized and perfectly understood Mendel's contributions but the explanation was not included in the final copy of his dissertation. In March 1900, Hugo deVries published the first of his two papers on genetics. The first was a brief note in Comptes Rendus - a journal of the French Academy of Science (de Vries, 1900). In this note he listed artificial hybridization experiments with 11 species in which he observed segregation patterns for various traits. Seeds from $\mathrm{F} 1$ hybrids produced between $22 \%$ to $28 \%$ plants with recessive traits, which he averaged to be $25 \%$, therefore concluding a ratio of 75:25 or 3:1 dominant to recessive progeny as was reported by Mendel. However, he did not mention Mendel in his first paper. His second paper, that was published in a German journal, was longer and included data on an additional five species. He mentioned that he had found Mendel's paper after his investigations. At this time, deVries was already famous for his work on mutations, a treatise being published in 1901. His studies on genetic mutations were important in establishing the gene-trait relationship.

Carl Correns, a student of Nägeli (a regular correspondent of Mendel), published an article 1 month after deVries, in Reports of the German Botanical Society, titled "Gregor Mendel's Rules Concerning the Behavior of Racial Hybrids." He noted the same results as deVries and mentions exact results of Mendel. A quote from his paper tells it all: "But then I convinced myself that the Abbott Gregor Mendel in Brunn (Brno), had during the sixties, not only obtained the results through extensive experiments with peas, which lasted for many years, as did deVries and I, but had also given exactly the same explanations." He was the first researcher to assign one factor of inheritance to one character and the first to suggest that segregation was related to meiosis. He also suggested the concepts of codominance and linkage. (Correns, 1900)

The third discoverer was Erich Tschermak, of the University of Vienna, who published in June 1900. He had initiated his research in 1898 with peas and came to the same conclusions as Correns.

William W. Sutton observed homologous pairs of chromosomes in grasshopper cells in 1900. In 1902 Walter Stanborough Sutton stated that chromosomes are paired and may be the carriers of heredity. He 
suggested that Mendel's factors are located on chromosomes; he went on to develop the chromosomal theory of heredity. Sutton named Mendel's factors genes. In 1903 Sutton and T.H. Boveri proposed that each egg or sperm cell contain only one of each pair of chromosomes. This led to an understanding of the interrelationship of chromosomes, meiosis, and genetics; this later would form the cytological basis of Mendelian heredity. Another giant of the early 20th Century was Wilhelm L. Johannsen of Denmark who defined genotype and phenotype. He also suggested that genes were chemical bodies.

One of the strongest proponents of Mendelism was William Bateson, an English scientist who initiated his research in 1897. He is credited with communicating the first English translation of Mendel's paper in 1901. In 1904 Bateson demonstrated that some traits are not independently inherited. He is reported to have recognized the duality of dominant and recessive forms (allelomorphs) of a gene, and further defined homozygote and heterozygote. He developed into a powerfully persuasive supporter of Mendelian genetics and actually introduced the term genetics on 31 July 1906 at the Third Congress on Hybridization and Plant Breeding (renamed International Congress of Genetics): "I suggest for the consideration of the Congress the term Genetics which sufficiently indicates that our labours are devoted to the elucidation of the phenomena of heredity and variation; in other words, to the physiology of Descent, with implied bearing on the theoretical problems of the evolutionists and the systematists, and application to the practical problems of breeders, whether of animals or plants." Bateson inflamed the evolutionists who were not about to accept the universality of Mendel's findings and started a war that would last for nearly 30 years between the Mendelists and Biometricians.

In the next several years, countless scientific findings supporting Mendelian genetics were observed. Scientists at Columbia University including Edmund B. Wilson and Thomas Hunt Morgan with their colleagues and students completed the story of chromosomes and genes. Morgan was awarded the Nobel Prize for this work in 1933 (Morgan et al., 1915).

\section{THE SCIENCE AND PRACTICE OF FLOWER AND NURSERY PLANT IMPROVEMENT}

Even from the first reported hybrid in Dianthus by Fairchild, ornamental plants have been used to enhance our understanding of genetics. Perhaps the earliest scientist to use Mendel's genetics in ornamental plant improvement was C.C. Hurst (1905). He initiated his studies in the 1890 s and in the following 3 decades published many papers on orchids, wheat, peas, moss rose, and Rosa. In 1906 he published a paper titled "Mendelian characters in plants and animals." Another early Mendelist was William Stuart of the Vermont Agricultural Experiment Station who investigated genetics of the carnation (Stuart, 1912).

Two of the most prominent horticulturists of the early 20th Century were Luther Burbank (1849-1926) (Fig. 1) and Liberty Hyde Bailey (1858-1954). Burbank worked in California and Bailey in Michigan and New York (Fig. 2). Burbank, the breeder, is credited with the development of hundreds of improved horticultural cultivars including the Shasta daisy. His first publication on plant breeding is dated 1902. Bailey, the scientist, published many basic and practical articles and books on all areas of plant science including a dozen on plant breeding; the earliest article on breeding was published in 1892. Bailey's six volumes of The Standard Cyclopedia of Horticulture were published in 1914. This reference is considered to be one of most influential books of the century. Revised editions appeared during the next 4 decades.

Some other early highlights include the publication in 1906 of Paul Knuth's Handbook of Plant Pollination, in 1907 Hugo de Vries' Plant Breeding: Comments on the Experiments of Wilson and Burbank, and in 1910 de Vries' The Mutation Theory. John Coulter published an early book on plant breeding in 1914.

In The Genetics of Garden Plants, Crane and Lawrence (1938), of the John Innes Horticultural Institution, reviewed investigations by a Hall of Fame group of early geneticists. The authors reviewed research on Primula (Bateson and Gregory, de Winton and J.B.S. Haldane), Matthiola (Correns, Tschermak, Saunders, etc.), Lathyrus (Bateson, Saunders and Punnett), Rudbeckia (Blakeslee), and Antirrhinum (Baur, 1918). They also reported investigations on Tropaeo- lum (Correns), Campanula (Bateson), and Viola (Clausen). These pioneering studies focussed on genetics, cytology, mutations, irradiation, and incompatibility. Also the chemical basis of flower color featured research on Dahlia. The authors discussed interspecific hybridization of Primula, Godetia, Iris, and Delphinium. In other topic-oriented chapters there are numerous references to ornamental plants. In Appendix 1, they listed the chromosome numbers of 51 genera of ornamentals. (Crane and Lawrence, 1934, 1938)

I believe that the most influential publication of the first half of the century on the genetics of ornamental plants was the extensive article by S.L. Emsweller (Fig. 3) et al. in the 1937 Yearbook of Agriculture (107 pages plus a separate supplement that contained 564 references). In this publication the authors summarized the published research that had been conducted on the genetics and breeding .of ornamentals. The stated purpose of the article was to encourage professional breeders to use a scientific approach to plant improvement. Emsweller's paper was aided by an earlier publication prepared by Warner et al. (1934) (USDA Librarians) that contained 10,156 references on plant genetics.

In the 1937 Yearbook of Agriculture one also finds an article by R.T. Cook (1937) titled "A Chronology of Genetics." This superb treatise reviews genetics of all organisms but includes numerous references to ornamental plants. What I like about this article is the author's inclusion of a statement by Thomas Hunt Morgan, one of the greatest geneticists, on the future of genetics.

Griesbach and Berberich (1995) in their article "The Early History of Research on Ornamental Plants at the U.S. Department of Agriculture from 1862 to 1940 " detail the many contributions that federal investigators made to the knowledge base on the genetics and breeding of both herbaceous and woody ornamental plants. These contributions continue into the new millennium at the National Arboretum, Beltsville, Md., and other ARS laboratories.

\section{MAKING A DIFFERENCE}

I offer a personal list of some scientific breakthroughs that I believe established the knowledge base from which modern ornamental plant improvement has developed. I realize that this list is incomplete, however its completion could be the topic for a future colloquium of the ASHS Ornamental Plant Breeding Working Group. I have included applications to ornamental genera with the understanding that the earliest application may have been with other genera. Also, some of these comments are from my memory or from unpublished articles that have not been previously recorded.

Mutations. It is reported that in 1902, de Vries, working with Oenothera (evening primrose), developed the "Mutation Basis of Evolution." Baur, in research published between 1907 to 1930, described and illustrated hundreds of mutant phenotypes in Antirrhinum. Many early scientists, including T.H. Goodspeed at the University of California, experimented on X-ray-induced mutations. C. Broertjes, ITAL, Wageningen, made great advances in mutation breeding of asexually propagated ornamentals later in the century. The arsenal of mutagens that have been investigated includes radiation-based mutagens, chemical mutagens, transposons, and ion beams.

LinKAGE. It is interesting that Bateson, Saunders, and Punnett (1905) demonstrated linkage (coupling) in sweet pea (Lathyrus). In this discovery, Bateson, the great defender of Mendelian heredity, presented a major challenge to Mendel's laws. Bateson also had serious doubts about the relationship between Mendel's factors and chromosomes. He had not accepted the chromosomal basis of genetics that was develop- 


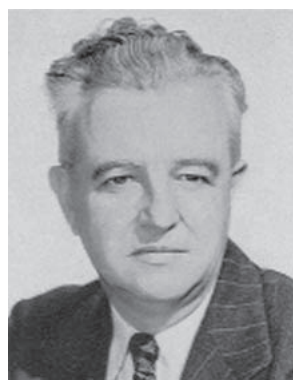

Fig. 3. Samuel Emsweller. ing in the first 2 decades of the century. $\mathrm{He}$ was still adamant about not accepting the explanation in 1916. After Thomas Hunt Morgan's brilliant research, Bateson started to relent and when asked by a reporter "Do you accept?" he answered "Yes, I do and all of my life's work has gone for nothing!" By 1921, even Bateson was convinced and his conversion was complete.

Hybridization. Interspecific hybridization of ornamentals has resulted in many award-winning cultivars. Advances in Dianthus improvement are based on combining favorable traits from different species. An interesting story of one person's dedication is that of Ronald Parker, now retired from the University of Connecticut. His research on Catharanthus created stunning new flower colors and other horticultural variants (Kemper, 1994). Boyle and Stimart (1982) and his students used interspecific hybridization to transfer disease-resistance genes in Zinnia. Linda Laughner (1985) transferred rust-resistance genes from the ivy-leaf geranium (Pelargonium peltatum) to the zonal geranium $(P$. xhortorum). Interestingly, the zonal geranium and the regal Pelargonium $(P . \times$ domesticum) are interspecific hybrids. Legro (1961) conducted significant research on interspecific hybridization of Delphinium in the Netherlands.

Ernst Benary in 1909 introduced the first commercial F1 hybrid flower Begonia gracilis 'Prima Donna' (Ewart, 1981, Benary, 1993). I believe that he was the first person to use the term heterosis for his hybrid begonias; the term was later trademarked. Benary has existed since 1843 and continues to introduce outstanding cultivars. Some sources indicate that Shull was the first scientist to use heterosis to describe the vigor of F1 hybrids in 1916. Until the 1940s, except for some pioneering work on hybridization (Benary in Germany and Sakata in Japan), most genera were available as open-pollinated, inbred, or asexually propagated cultivars.

The change from open-pollinated and line-bred cultivars to F1 hybrids was the major change that occurred in the century. In 1934 Sakata was awarded one of the earliest All-America Selection (AAS) awards for the first F1 Petunia 'All Double Victorious Mixed'. Separate colors were introduced and received AAS awards in subsequent years. Sakata gained dozens of AAS awards during the next 7 decades. In 1950, Bodger Seed introduced the first red-flowered Petunia 'Firechief', a line-bred cultivar. This was followed in 1953 when the red-flowered F1 hybrid 'Comanche' was introduced by PanAmerican Seed Company. Early development of F1 hybrid petunias and other crops resulted from the brilliant guidance of Charles Weddle, W.D. Holley, and Claude Hope (Fig. 4), founders of PanAmerican. F1 Viola (pansy), Ageratum, Tagetes, Dianthus, Pelargonium, Zinnia, and others followed. Craig (1994) lists 25 genera of ornamentals that were available as F1 hybrids. Impatiens in all of its forms was one of the most significant achievements of the century. Claude Hope, Linda Vista, S.A. in Costa Rica, domesticated Impatiens wallerana; he developed world-class F1 hybrids. Modern Impatiens are available in a rainbow of flower colors and patterns and have been developed for both shade and sun gardens. (Martinez, 1997).

Pollen Control Strategies. With the advent of F1 hybrid cultivars, seed production protocols experienced great changes. Economical production of F1 seed required the use of pollen-control methodologies. A major advancement in plant breeding resulted from our understanding and use of genetic, cytoplasmic, and genetic-cytoplasmic pollen sterility. Petunia was an early model plant. A 1966 report from the USDA stated that their scientists had discovered cytoplasmic sterility factors in Pelargonium, Cineraria, Taxus, Rosa, and Euphorbia. Morphological (functional) sterility has been used in F1 hybrid production of Tagetes and Zinnia, a particular benefit in Compositae. Antirrhinum and other genera exhibit unique sterility systems. Ultimately, F1 hybrid production was moved offshore to locations with lower labor costs and more ideal climates.

The recognition of pollen incompatibility in Nicotiana (East, 1915) and in many floricultural crops including Primula was an important step in understanding the genetics, physiology, and behavior of pollen.
More recent research on Chrysanthemum and Lilium by Peter Ascher (1976) and a large group of graduate students at the University of Minnesota led to a more universal understanding of incompatibility. Many of these former students have made significant contributions to the breeding of ornamental plants. Teh-Hui Kao and colleagues at Pennsylvania State University (Lee et al., 1994) demonstrated the ultimate explanation of the molecular genetic basis of gametophytic self-incompatibility in Petunia. Self-incompatibility has been used in the production of Ageratum F1 hybrids. Many excellent scientists spent much of their professional lives investigating this phenomenon.

The scientific advances in pollen physiology were documented by James Brewbaker (1959) who assembled information on hundreds of species and cross-categorized plant families with respect to the number of cells in a pollen grain at maturity, types of incompatibility, germination in vitro, and other traits. Many investigators have used ornamental plants. Leaders in this field are highlighted in de Nettancourt (2001); there are 44 pages of references. In the index one finds the following genera: Amaryllis, Anchusa, Antirrhinum, Bougainvillea, Chrysanthemum, Cosmos, Crocus, Hemerocallis, Papaver, Petunia, etc.

Polyploidy. Polyploidy, including both euploidy and aneuploidy, has played a significant role in the evolution and improvement of ornamental plants. Digby described a tetraploid Primula kewensis in 1912. Winkler made experimental observations of polyploidy in callus tissue in 1916. G. Tackholm (1920) observed polyploidy in Rosa. Primula kewensis was the first amphidiploid to be noted (Cook, 1937). Bamford and Winkler (1941) documented a spontaneous tetraploid Antirrhinum. Fred Winkler is a superb plant breeder and some of his snapdragon cultivars are still available in the trade. Tetraploid Cyclamen, Pelargonium, and Zinnia have been important in the development of improved cultivars. Many cultivars of herbaceous perennials, fresh cut flowers, bulbous crops, flowering trees, and asexually propagated genera of ornamentals are polyploid. This topic was reviewed by L.D. Sparnaaij (1979) of Wageningen and has been discussed in several national and international conferences.

Colchicine-induction of polyploidy by Blakeslee and Avery (1937) was an important event. Ruttle and Nebel (1938) produced colchiploids of Tagetes, Dianthus, and other genera. A haploid plant of Lycopersicon esculentum 'Marglobe', one of the most important line-bred tomato cultivars for the home garden, was colchicine-induced to produce a double-haploid inbred (Cook, 1936). Emsweller (1941) reviewed the early research on induced polyploidy. Colchicine has been used to produce autotetraploids and amphidiploids in numerous genera from Antirrhinum to Zinnia. Some commercial herbicides are also reported to be useful in tetraploid induction, including Oryzalin (Surflan), Treflan (trifluralin), Dimension (dithiopyr), and Visor (thiazopyr) (Grazzini, personal communication).

Chimeras. Our understanding of histogens and chimeras was furthered by early research by Winkler (1916). Investigations were conducted on many ornamentals including Pelargonium, Cytisus, and Crataegus. Sagawa and Mehlquist (1957) at the University of Connecticut conducted brilliant work on the mechanism of $\mathrm{x}$-ray-induced mutations in Dianthus. H. Dermen (1960) and colleagues at Beltsville (USDA-ARS) conducted extensive research on chimeras in horticultural plants. I should also note the epic work by Tilney-Bassett (1963) with Pelargonium. These studies have spawned the introduction of cultivars with novel flower colors, bract colors (Stewart and Arisumi, 1966), and foliar variegation patterns. Marcotrigiano (1997) wrote a recent review of chimeras and mosaics.

Floral Pigmentation. I have been entranced by the development of cultivars with floral pigmentation that is not observed in ancestral species. A perfect example is Saintpaulia ionantha, the African violet. This plant was first introduced into Europe from Kenya and Tanzania 
in 1892. All species have flowers that are shades of blue; however, modern cultivars display a wide range of flower colors and patterns. David Burpee's white marigold (Tagetes) competition gained national prominence in the 1950 s. I remember seeing many acres of seed production of the green-flowered Zinnia elegans 'Envy' during one of my visits to California. Clark D. Paris et al. (1960) published an important technical bulletin titled A Survey of the Interactions of Genes for Flower Color. This was Paris' dissertation at the Michigan State University and included 111 references.

Flower color (flavonols and carotenoids) of ornamentals has been important in the elucidation of the relationship of genetics and biochemistry. C.C. Hurst (1905) demonstrated a two-gene model for flower color in orchids. This trait has attracted the interest of dozens of reputable researchers in many disciplines. Interestingly, Cook (1937) suggested that biochemistry would be the next challenge for genetics. He stated "It is probable that we are even now witnessing the development of another major branch of the genetic tree - the biochemical branch. It has long been guessed that genes must be chemical in their action. And the molecular action of genes has more than once been suggested and speculated on." Plant pigments, for example lycopene, have taken on greater importance as they are being related to important health issues.

GermPLASM. The acquisition, propagation, preservation, and distribution of ornamental plant germplasm have been primarily the role of the USDA and botanic gardens, arboreta, and conservatories. During the 20th Century many explorations were conducted to secure germplasm of ornamental plants. Similar activities, directed to specific taxa, have been part of many university breeding and genetics programs. Many floral and nursery corporations have collected and introduced new cultivars. Significant breeding, genetic, and cytological investigations were conducted on a multitude of genera. While much attention has been given to woody ornamentals, herbaceous plants have also been investigated. The National Seed Laboratory in Colorado is important for the preservation of seed propagated germplasm. In 2001, the Ornamental Plant Germplasm Center in Columbus, Ohio, was established primarily to preserve herbaceous genera. It is a joint venture of The Ohio State University and USDA-ARS with the support of industry. Its mission is aligned with the National Plant Germplasm System (NPGS). It was formed as an outgrowth of Herbaceous Ornamental Crop Germplasm Committee (HOCGC) that was formed earlier to develop a priority list of genera where germplasm activities are needed. Ewart (1981) provides an interesting view on the use of flower germplasm. He develops a unique historic view from 4000 BC to the present. An excellent summary of the botanical, breeding, and historic background on the HOCGC priority genera can be found at http//www.ars-grin.gov. Similar activities are being conducted within the NPGS with woody ornamentals, shrubs, and trees. The National Arboretum, several other arboreta, and other USDAGermplasm Centers are involved in preserving these collections. The Convention on Biodiversity is beginning to affect the exchange of germplasm; it will be interesting to observe the long-range effects of this convention. I feel that exchange is the keyword; however, the currency that will be exchanged has not yet been universally defined.

Improvement of Asexually Propagated Crops. When I first entered horticulture in 1951 some or all cultivars of many genera were still primarily asexually propagated. Over the next few years plant breeders developed seed-propagated Ageratum, Antirrhinum, tuberous Begonia, Petunia, Verbena, and Pelargonium. The converse is occurring in 2003; asexually propagated cultivars are being introduced in genera that have been usually seed propagated. These crops include Antirrhinum, Petunia, and Verbena. Some crops have important cultivars, e.g., zonal geraniums, which are propagated both sexually and asexually. The bottom line is that we are into an exciting age and both old and new companies have plant improvement programs for both sexually and asexually propagated cultivars.

Model plant improvement programs have been conducted on several of the most important asexually propagated florist and garden genera for more than 5 decades. Yoder Brothers created the breeding and cultural protocols for Chrysanthemum (Dendranthema); to me William Duffett is one of the most productive and creative plant breeders in the world. Several generations of the Ecke family have been responsible for the continual improvement of the poinsettia (Euphorbia pulcherrima). Bob
Oglevee is credited with impressive improvements in Pelargonium and several other crops. Jim Mikkelsen conducted important cultivar developmental research on Begonia, poinsettia, New Guinea Impatiens, etc. 'Paul Mikkelsen' poinsettia became the first cultivar that displayed extended longevity as a potted plant. This cultivar set a new genetic standard for plant breeders. Similarly Ecke Ranch's discovery of the branching factor and its enlightened breeding program further improved this crop and made it one of the most important floral crops in the U.S. These entrepreneurial enterprises are detailed in Meister Publishing's History of U.S. Floriculture (Onofrey, 1999). Many of these cultivar development programs had their birth either at the USDA or in university laboratories.

One of the most significant developments of the century with respect to asexually propagated crops was the New Guinea Impatiens. Germplasm was collected through a collaborative effort of the USDA and Longwood Gardens in 1970 (Winters, 1973). The first cultivars were named the Circus series by Longwood and the Painted series by the USDA. Breeders of these cultivars were T. Arisumi (USDA) and R. Armstrong (Longwood). Subsequent research at Iowa State University and commercially by James Mikkelsen of Ashtabula, Ohio, enhanced the development of commercial cultivars. Ultimately several other U.S. and international firms initiated breeding programs. To date hundreds of cultivars have been introduced.

Such genetic advances with asexually propagated genera were dependent on the development of clean stock systems that in turn were dependent on tissue culture protocols. Leaders in the development of clean stock systems, originally developed at the University of California, were Yoder Brothers and Oglevee Ltd. The most well-known champions of clean stock systems for ornamental plants were Kenneth Baker in California, Kenneth Horst at Cornell, and James Tammen and Sam Smith at Pennsylvania State University.

New CRops. During the last quarter of the century an increasing interest was generated in new crops. Dozens of new species and genera enter the commercial arena each year. Some new cultivars are only selections; others are the result of intra- and interspecific hybridization. Some of my favorites are Eustoma (Lisianthus), a native American species improved in Japan, Costa Rica, and Florida (Harbaugh, 1996); Osteospermum from South Africa, the font of a multitude of ornamental germplasm; native texas blue bonnets (Lupinus) by researchers at Texas A\&M; and Alstroemeria from Peru but improved in The Netherlands and in Connecticut. New organizations have emerged that introduce these new plants into commerce. One example is Chicagoland Grows Inc., a consortium of the Chicago Botanic Garden, Morton Arboretum, and the Ornamental Growers Association. Wilkins and Erwin (1998) offer considerations involved in the introduction of a new taxon.

Winter-hardy herbaceous perennials have received a great deal of breeding attention from commercial and private breeders; conversely, few genetic and cytological investigations have been conducted with these plants. Improved cultivars of dozens of genera have been developed namely Hemerocallis, Hosta, Dahlia, Hibiscus, etc. More research is required to ensure second year flowering, understand seed dormancy, and improve seed germination. I recently read a catalog on aquatic plants and was amazed at the cultivar development that has occurred in this industry. It is also apparent that significant improvements have been made in the improvement of ornamental grasses.

Perennials and Nursery Crops. Nursery crop genera have received the attention of public and private plant breeders. Exciting cultivars have been introduced by The National ArboretumUSDA-ARS (Glenn Dale azaleas, Viburnum, crape myrtle), the Connecticut Agricultural Experiment Station in New Haven, Arnold Arboretum of Harvard University, University of Minnesota, West Virginia University, and Rutgers University. Improved traits are dwarfism, foliar variations, flower and fruit color, sterility (for absence of fruit), noninvasiveness, and winter hardiness. Interesting new cultivars have been developed in Ulmus, Acer, Weigelia, Ilex (e.g., I.meservae), Hydrangea, Malus, and Cornus. Perhaps the most attention has been given to Rosa for fresh flower production, potted plants, and garden plants. Public and private research in many nations has created roses of exceptional beauty and quality. The names Conard-Pyle (Star Roses), Jackson-Perkins, Delbard, and Meilland are internationally recognized for their excellent cultivars. 
Plant of the Century. My nomination for the ornamental plant of the century is Petunia. Early F1s, model plant for physiological investigations including pollen sterility and incompatibility, resurgence in the 1990s as asexually propagated cultivars and ultimately by 'Wave' (Fig. 5). These new cultivars set new standards for floriferousness in the garden. With its close relationship to Nicotiana it was a natural choice for somatic hybridization research. It is one of the favorites of molecular biologists. This genus fueled the bedding plant industry's growth in the latter half of the century (Larson, 1992).

\section{EMERGENCE OF BIOTECHNOLOGY}

Modern biotechnology is a combination of tissue culture protocols and molecular biology. Tissue culture protocols are the foundation for the development of many diverse biotechnologies that are used in the genetic improvement of plants. The development of growth media was an important first step (Murashige, 1974). The clonal propagation of orchids was one of the earliest applications of tissue culture. One of the results is that orchids, once a plant only for specialists, are the second most important pot-grown plant in the U.S. Tissue culture for multiplication purposes is also important in the latter stage of a breeding program for the production of commercial quantities of a new cultivar. Whole-plant regeneration of Daucus (carrot) from single cells by F.C. Steward at Cornell University in 1958 startled all of science and gave promise that cloning was a possibility. Somatic hybridization (protoplast fusion) research was furthered by studies on genera within the Solanaceae including Petunia (Power et al., 1970 and 1977; Sink and Power, 1977). Griesbach (1988) provides an extensive review of protoplast biology in flower crops.

One of the most advanced tissue-culture technologies is somatic embryogenesis; the production of somatic embryos and cloned progeny from somatic cells. This protocol can be automated through the use of bioreactors. Many researchers have demonstrated successful somatic embryogenesis in ornamental plants. This protocol potentially can be useful in breeding programs. Somatic embryogenesis was demonstrated to be a genetically conditioned trait in Pelargonium at the University of Guelph (Marsolais et al., 1991). This was a significant event in plant breeding.

The observation of clonal variation by W.D. Holley in Colorado in a single cultivar of greenhouse fresh flower roses proved that even asexually propagated cultivars could exhibit genetic variation. Thus, we were not surprised to observe mericlonal variation in plants derived by meristem tip-culture of Pelargonium $\times$ hortorum cultivars (Craig et al., 1979). These plants were cloned from individual meristems at Oglevee Ltd. in Connellsville, $\mathrm{Pa}$., as part of their culture-virus-indexing program in 1977. Mericlonal variation was observed in both greenhouse and field experiments. Furthermore, calliclonal variation was observed by Skirvin and Janick (1976) in Pelargonium. Somaclonal variation, such as that investigated by Bridgen (Hadi and Bridgen, 1996) in Torenia, suggested a new source of genetic variation that could be useful in plant improvement. One can add gametoclonal variation as an additional tool (Evans, 1988).

Molecular biology derives its power from biochemistry, biophysics, cytology, genetics, and physiology. In1869, Friedrich Miescher, a Swiss scientist, discovered DNA. His discovery was first related to genetics in 1941 and brought to life by James Watson and Francis Crick in 1953 (Watson et al., 1953). Watson, Crick, and Maurice Wilkins were jointly awarded the Nobel Prize in Medicine for their research in 1962.The age of molecular biology began when these scientists elucidated the structure of DNA.

Palmer et al. (1987) described the largest chloroplast DNA molecule to that time in tetraploid Pelargonium $\times$ hortorum. Such research is important in systematics and it also has significant evolutionary implications. In addition, it directs us to more fully consider the importance of chloroplast and mitochondrial genomes. The research suggests that subnuclear genomes can be additional sources of useful genes for plant improvement.

The ability to transform plants was a major achievement of the last 2 decades of the 20th Century. Agrobacterium-induced transformation is the protocol of choice and has been used with many species. The discovery of biolistics (the gene gun) by Cornell University researchers

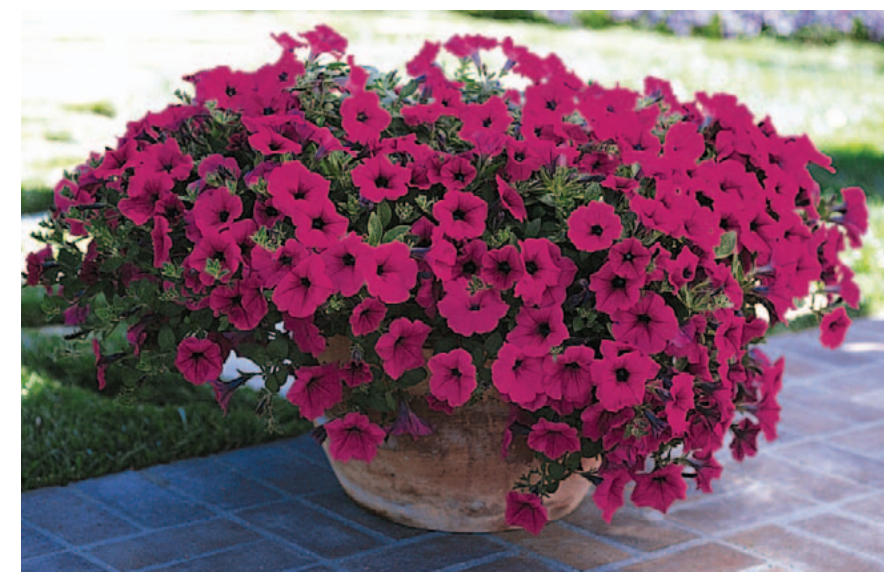

Fig. 5. Petunia - plant of the century. Petunia 'Wave', an All-America Selections winner. Photo courtesy of Ball Horticultural Company, West Chicago, Ill.

at the New York Experiment Station at Geneva (Klein, 1987) marked a milestone in plant genetics research. John Sanford, one of the developers, retained the rights to use this technology on ornamentals. I understand that he entered into agreements to develop commercially acceptable cultivars. Although progress has been demonstrated with transformation, few transformed cultivars of ornamental genera have been released. Florigene, in Australia, introduced a blue-flowered transgenic carnation (Dianthus caryophyllus) called 'Moondust' in 1996. In 2001, Florigene introduced 'Moonlite' and 'Moonvista' carnations.

The current interest in genomics has spawned a series of useful applications including quantitative trait loci (QTL) analysis and markerassisted selection (MAS) and crop improvement strategies. Deroles et al. (2002), in Breeding for Ornamentals: Classical and Molecular Approaches (Vainstein, 2002), list 32 genera of ornamentals from which transgenic plants have been generated. This volume includes numerous chapters by qualified scientists and extensive references. This book summarizes the state of the art of the biotechnology of ornamentals.

A great deal of information is being developed on the genetics, architecture and physiology of roots. Unfortunately, this is an area that has received only limited attention of plant geneticists; however, it is critical when breeding for the efficient use of nutrients or tolerance to abiotic stresses such as drought and salinity. The genetics of rootmycorrhizal associations also deserve additional research.

Currently, molecular genetics and breeding research on ornamentals is being conducted throughout the U. S. and internationally by academic, federal, and industrial researchers. Some industrial programs are conducted by old-line floricultural companies - Ball Helix, by established companies whose primary interests are not horticultural-Kirin and Calgene, and by new organizations dedicated to ornamental plant improvement-Florigene.

\section{CONCOMITANT DEVELOPMENTS IN THE ASSOCIATED SCIENCES}

Progress in any given science does not occur in a vacuum; this is particularly true for the genetics and breeding of ornamentals. To their credit plant geneticists evolve with respect to the scientific environment in which they work. The past century provides much evidence to support this fact. Some of the mutual advancements result from our educational system. Students are exposed to the newest technologies and scientific concepts. Teachers have opportunities for continuing education through sabbaticals. Further, funding agencies stimulate research directions.

No discipline can survive without a historic foundation. The foundation of plant breeding and genetics is germplasm as preserved in herbaria and in living collections. Most herbaria preserve specimens of ornamentals. Since the Middle Ages herbaria and the knowledge that they provide have sustained horticulture. Of particular importance to our discipline are the collections at the Bailey Hortorium at Cornell University, Arnold Arboretum at Harvard University, The National 
Arboretum, New York Botanical Garden, and Missouri Botanical Garden. A more complete list of herbaria may be obtained from the American Association of Botanical Gardens and Arboreta (AABGA). I should note that the substantial changes in systematics that occurred during the 20th Century. At the turn of the century, morphological systematics was in vogue. Later, numerical systematics and biochemical systematics emerged. At the end of the century, molecular systematics became possible.

Seeds are the ingredients and products of plant breeding. Great advances in seed technology occurred in the century. Improved technologies were developed for seed harvesting, processing, seed analysis, packaging, and germination. Innovative research was conducted on a broad front in federal and university laboratories, e.g., Cornell University, Oregon State University, and Mississippi State University, at the USDA, and within the industry.

The development of computers, data acquisition, storage and retrieval technologies, and the Internet were paramount to the development of science in the past 40 years. Invention of solid-state analytical devices, microequipment, and intelligent sensors was spawned by our nation's commitment to the space program. The national commitment to the human genome project has resulted in the development of equipment and protocols that are now being applied to ornamentals. We are still harvesting technologies from these efforts. Engineering and architectural advances including greenhouse and nursery automation resulted in production efficiencies. I believe that the development of plug-culture technology was one of the most important developments of the century. When ultimately coupled with bioreactor-based somatic embryogenisis it will be the production protocol of choice for the 21 st century.

Knowledge of the chemistry and physiology of plant growth regulators - especially gibberellic acid, cytokinin, auxin, and ethylene - is critical for the current research in molecular genetics and genomics. One other exciting change that occurred in the latter part of the century was directed research on ornamental plants that have unique pharmaceutical properties. This, of course, has been known by botanists for several millennia and is the basis for many herbal remedies. Two of early candidates were Catharanthus (alkaloids) and Taxus (Taxol). They are sources of potent anti-cancer drugs. Their activities and structures led scientists to the discovery of less cytotoxic and more effective drugs.

One cannot be a modern plant breeder without knowledge of and collaboration with scientists in related disciplines. Of critical importance are scientists who study soils (agronomy), plant physiology, agricultural engineering, plant pathology, and entomology. Strong collaborations have led to the elucidation and application of many genetic phenomena and the production of unique cultivars.

\section{FUNDING OF RESEARCH AND DEVELOPMENT}

Substantial and continuing funding for research has been provided by the USDA-ARS and the agricultural experiment stations located throughout the nation. Some research is funded by other federal and state programs. Examples of national funding agencies are the National Science Foundation, the National Institutes of Health, and the Small Business Administration. Much of our early research at Pennsylvania State University was funded by the Ben Franklin Partnership Program; an economic development program that is funded by the commonwealth, industry and university. Similar programs are in place in other states and funding has been appropriated in support of research on ornamental plants, e.g., Yankee Ingenuity Technology Competition in Connecticut.

There has been an increase in the number of foundations that provide research grants for floriculture and ornamental horticulture in support of classical and molecular breeding and genetics research and development: The Horticultural Research Institute, the American Floral Endowment, the Fred C. Gloeckner Foundation, the Joseph Hill Foundation (Roses Incorporated), Bedding Plants Incorporated Foundation, and Ohio Florists Foundation. The latter two foundations recently merged into Floriculture First. Many state trade associations dedicated to floriculture and nursery crops fund research. In addition, within the past 5 years, the Floriculture and Nursery Research Initiative included in the federal Farm Bill, has provided significant funding for research on floral and nursery plants. Many plant societies such as the American Orchid Society, the American Hosta Society, and the African Violet
Society of America support scientific research. Individual corporations have established foundations that support research: J. Frank Schmidt in Oregon, Spring Meadow in Michigan, and the Paul and Magdalena Ecke Foundation in California.

\section{THE SEED INDUSTRY}

A critical treatise that is not readily available is the information assembled by James Nau (2000) in American Seed Houses in the 18th and 19th Century. My copy is from the Ball Seed Company archives. Nau presents this information as a talk. With respect to the title he brings the industry well into the 20th Century. Some of the companies portrayed in his presentation were still in existence in some form in the last decades of the 20th Century, e.g., Breck (1822), Bodger (1890), Sluis and Groot (now S\&G) (1867), Ball (1905), and Burpee (1876). I would be remiss if I failed to mention the substantial contributions made by Waller Seed, Denholm Seed, Park Seed, and the Joseph Harris Seed Company. Most of these companies were formed by entrepreneurs with unique talents in plant breeding. Multinational corporations, both public and family owned, are now the primary commercial sources of new cultivars of floricultural products. Nursery crop breeding seems to have a broader base with respect to improved cultivars.

In 1933, W. Ray Hastings (Fig. 6) chartered All America Selections (AAS). This elite organization evaluates the garden performance of floricultural plants throughout North America and awards medals for exceptional performance. AAS also evaluates garden vegetables and roses. AAS can take credit for much of the improvement in ornamental plants that has been realized during the past 70 years. One has only to review the list of winners and the global basis of the awardees to come to that conclusion. In Europe, Fleuroselect and the former All-Britain Trials share a similar mission and high reputation. FloraStar is an organization that evaluates asexually propagated species. Various states have their own programs for evaluating and recommending improved cultivars of flowers, perennials, and nursery crops. Individual societies usually have new cultivar competitions.

Seeds. The Yearbook of Agriculture includes an article by Howard Bodger (1961), one of the prominent flower seedsmen of the century, on "The Commercial Production of Seeds of Flowers." In this same book are chapters on introducing new horticultural varieties by Boswell (1961), how we get seeds of vegetables and flowers by Carter and Bugbee (1961), and the seeds of wildflowers by Ricker (1961). These articles and the other 74 chapters summarize the state of the industry at that time. Seed industry trade magazines provide regular updates on both scientific and technological advances.

One of the more interesting developments in the industry was the emergence of seed and propagule brokers that neither breed new cultivars nor produce seeds or plants. These brokers are well established and some are more than 100 years old. They not only market floral and nursery products but provide valuable technical information to their customers.

Major changes in the structure of the industry began in the latter part of the 20th Century. One modification of both seed production and the production of asexual propagules is that more and more units are produced outside of the United States, Canada, and Europe. Offshore production has advantages such as favorable environments and

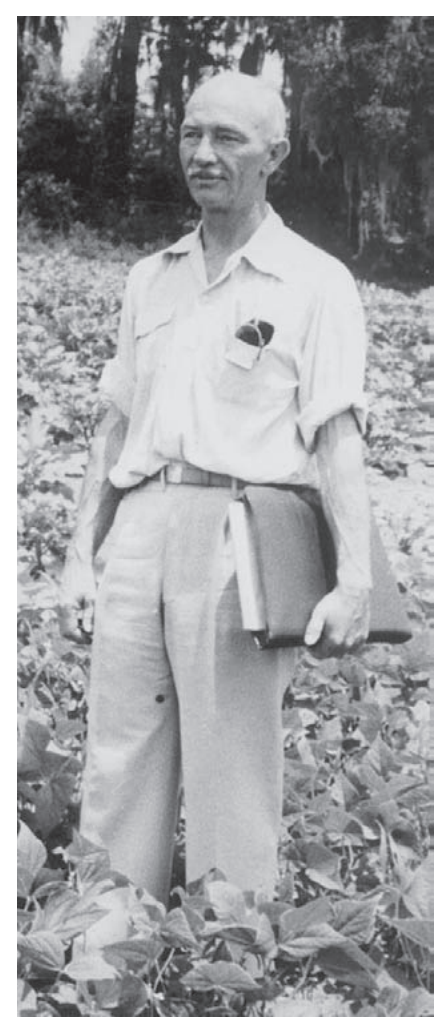

Fig.6. W. Ray Hastings. Photo courtesy of All-America Selections, Downers Grove, Ill. 
lower labor costs and disadvantages such as seasonal production, quality control, and phytosanitation measures.

There was a demise of family owned seed businesses; ownership often was transferred to corporations with no background in horticulture. Few of these acquisitions were permanent. Consolidations by horticultural firms seem to have been more successful. However even in family owned businesses that survived there often was a realignment of priorities and goals. Internationalization was important to the survival of many individual firms. Biotech-oriented laboratories reside in both large and small corporations.

It is apparent that research on ornamental plant breeding and genetics is and has been fueled by enormous growth of the bedding plant industry in the last half of the 20th Century (Larson 1992). Additionally the post-World War II growth of single-family residences and the later development of apartment and condominium communities led to growth of the nursery and landscape industries. These social factors stimulated the development of improved cultivars. Changes in the national fabric, the rise of individualism, and a quest for novelty were important in generating a demand for new and improved plants. Although we are now experiencing an economic lull, history indicates that these conditions are cyclic. I expect that the growth of the industry will continue in the future.

\section{INTELLECTUAL PROPERTY RIGHTS}

Ornamental plants played a substantial role in the development of intellectual property rights. The U.S. Congress passed plant legislation in 1930; thousands of asexually propagated ornamentals have been patented. In 1997, the 10000th plant patent was awarded to David Lemon of Oglevee Ltd. for Pelargonium $\times$ domesticum 'Lois' (Lemon, 2003). The Plant Variety Protection (PVP) Act (1970) was legislated to protect seed propagated inbred lines and line-bred cultivars; many flower lines and cultivars have received certificates. Finally, utility patents are used for protection of plants and plant-related inventions. Examples are the process for the production of year-round flowering of Pelargonium $\times$ domesticum (Craig and Oglevee 1990) and the desaturase and gene related to arthropod resistance in Pelargonium $\times$ hortorum (Craig et al., 1999). Dozens of reviews and conferences have been directed toward developing a better understanding of breeders rights. Several excellent reviews appeared in HortTechnology [vol. 3(3)] in 1993. In the past few decades a new type of organization has been founded; royalty administrators are now widely used to assist breeders in protecting their rights.

In 1988, the first plant patents (PP 6218, 6219, 6320, 6247, 6378, and 6379) to include quantitative HPLC anthocyanin and flavonol fingerprints were allowed for six cultivars of Pelargonium $\times$ hortorum that were developed at Pennsylvania State University. This technology was developed by Sam Asen (1983) at Beltsville, Md. Subsequently DNA fingerprints, using various molecular markers such as RAPD, RFLP, $\mathrm{SSR}$, etc., were used for intellectual property protection.

\section{PROFESSIONAL AND TRADE ORGANIZATIONS}

Several major professional organizations were chartered at the beginning of the 20th Century including the American Horticultural Society and the American Society for Horticultural Science (ASHS). ASHS has established Ornamental Plant Breeding, Floriculture, Nursery Crops, Ornamentals, Landscape and Turf, Genetics and Germplasm, and Intellectual Property Rights Working Groups, all of which are important to our discipline. The International Society for Horticultural Science (ISHS) was formed in 1864 and formally established in 1959. The Canadian Society was founded in 1956. In Europe, EUCARPIA (European Association for Research on Plant Breeding) was founded in 1956; it includes a section on ornamentals.

There have been numerous conferences, symposia, colloquia, and meetings where breeding and genetics research on ornamentals has been reported. Many of these events have resulted in published proceedings (Acta Horticulturae) available. ISHS has sponsored 20 international symposia on the improvement of ornamental plants. The first symposium convened in 1956 at the Michigan State University; the most recent symposium was held in Belgium in 2001. The ornamentals section of
EUCARPIA sponsors a conference at some international site, often with ISHS sponsorship, every few years; the proceedings are available. These conferences are an excellent blend of science and technology. The ASHS Ornamental Plant Breeding Working Group meets annually; abstracts often appear in HortScience. Botanic gardens such as Chicago Botanic Garden presented New Ornamental Crops Research Symposia in 2001.

Many trade organizations have been formed in support of the floriculture and nursery crop industries. Umbrella organizations include the Society of American Florists, American Seed Trade Association (the ASTA 43rd Vegetable and Flower Seed Conference is scheduled for 2004), Bedding Plants Incorporated (Professional Plant Growers), American Landscape and Nursery Association, and the Ohio Florists Association. Many state and regional organizations are active.

There are dozens of grass-roots organizations that are dedicated to the culture and improvement of ornamental plants. Members of these groups have been responsible for the introduction of thousands of improved cultivars. Some refer to their members as amateur breeders; I prefer the term private breeders. I cannot think of any important genus that is not represented by a regional, national, or international society. Many of these organizations meet often, publish regularly and sponsor, or stimulate the publication of manuals and pamphlets on breeding. I have collected such publications on the breeding of chrysanthemums, Saintpaulia, carnation, and snapdragon.

\section{THE PUBLISHED WORD}

An important event was the publication of the Handbook on Breeding Ornamental Plants by the Brooklyn Botanic Garden in 1959. This handbook included articles by public and private breeders on a plethora of ornamentals. The handbook was revised and published in 1976. (Anonymous, 1976). In 1957 the National Chrysanthemum Society published The Breeder's Handbook (Scott, 1957). The handbook included articles by academic plant breeders John Culbert of the University of Illinois and Glenn Viehmeyer of the University of Nebraska. William Duffett of Yoder Bros. also contributed a chapter.

A more recent treatment (Callaway and Callaway, 2000), Breeding Ornamental Plants, updates the state of the breeding of flowering shrubs and trees, two house plants, herbaceous perennials, bulbous crops, aroids, and oaks. In 2002 Vainstein edited Breeding for Ornamentals: Classical and Molecular Approaches. In this volume we find chapters by an international group of scientists. In section 2 there are five chapters on classical breeding with extensive references. Section 3 includes 10 chapters on the molecular genetics of important traits. Again the articles provide an excellent summary of current research directions.

\section{EDUCATIONAL COMPONENTS - A STEWARDSHIP ISSUE}

When we write the history of the breeding and genetics of ornamental plants it is easy to forget the contributions of universities, not the research component, but more important the educational component. The primary role of the university, particularly but not exclusively, is to educate the young men and women who make the breakthroughs in genetics and breeding. Industry and academic plant breeders have diverse educational experiences. Successful plant breeders have associate, bachelors, masters, and doctoral degrees. Creativity is seldom mentioned on a diploma. Many ornamental plant breeders are educated in genetics and breeding programs involving agronomic and other horticultural crops. Newer graduates often have been educated in molecular biology.

Many universities have made long-term commitments to the education and training of plant breeders. Michigan State University, University of Minnesota, University of Wisconsin, University of California, Rutgers University, University of Connecticut, University of New Hampshire, University of Nebraska, University of Florida, North Carolina State University, Cornell University, and Pennsylvania State University are some of these institutions. At several of these institutions two or three generations of faculty have been involved. The offering of academic courses, especially those directed toward the breeding of ornamentals, is a major mission of the university. One of the highlights at several universities has been the direct involvement of undergraduates in the 
research program. Industry sponsored internships enhance these educational experiences. One benefit of these university-based programs has been the education of women at all degree levels. There is much concern today about loss of academic positions in breeding and genetics. Conversely, several universities with no prior involvement in ornamental plant breeding have established such programs. Education does not stop at graduation, it continues for a lifetime. Many academics have been involved in this mission through presentations, publications, and personal conferences and visits.

\section{FUTURE PERSPECTIVES}

Our future will be directed by the prevailing science. Today we speak of genomics and protenomics; what about tomorrow? For more than a century flower and nursery plant breeders have both led and capitalized on scientific discoveries in the plant sciences. I have no doubt that we can achieve what we can imagine. The most critical areas are genetic resistance to arthropod pests, diseases, and tolerance to soil and atmospheric production barriers. Excellent articles on molecular biology of ornamental plants can be found in Clark (1996), Dudareva (2002), Mol et al. (1989), and Pelczar (2000). The developing understanding of genes involved in flower formation is a foretaste of the future.

\section{CONCLUSIONS－SOME PERSONAL REFLECTIONS}

One cannot think of genetics without thinking about Gregor Mendel. Individual achievements in the genetics and breeding of ornamental plants are often due to crop or discipline champions. One cannot consider Impatiens without thinking of Claude Hope. One cannot see a poinsettia without thinking of Paul Ecke Ranch in Encinitas, Calif. I have been privileged to know four generations of the Ecke Family. The recent death of Paul Ecke, Jr., has resulted in a great leadership void in national floriculture. I have known four generations of the Oglevee family. Bob was the father of modern geraniums and his father Ed was responsible for fostering development of the regal Pelargonium. Bob's daughter, Wendy, proved that perseverance and discipline with culture and virus-indexing protocols could lead to long-term production of clean stock. John Vaughan was a role model for both academics and industry personnel; his vision of the industry and his business acumen were extraordinary. The several generations of the Ball family served the grower, retailer, and consumer of horticultural products and information for many decades. Growers Talks and the Ball Red $B o o k$ were the texts that educated generations of growers, marketers, students, and researchers.

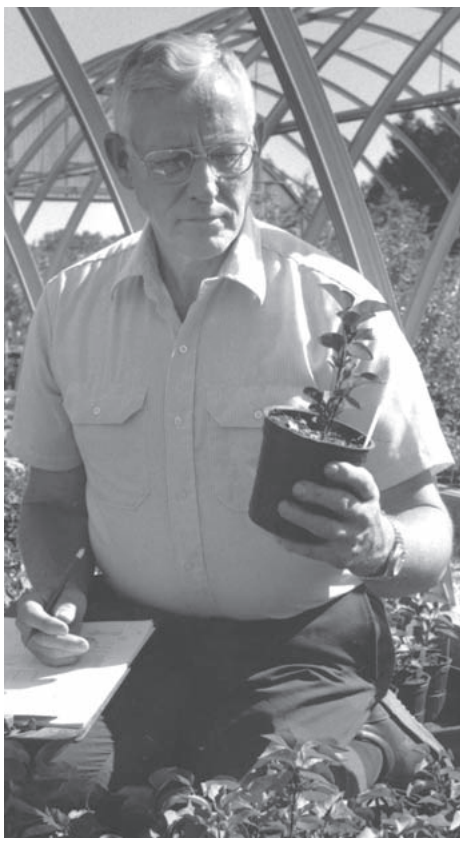

Washington Atlee Burpee and his son David gave the Burpee name a national recognition. Located in Pennsylvania and California this company bred new cultivars and marketed them wholesale and through mail-order and packet sales. He had the political connections to have the marigold nominated as the national flower. I remember, as a graduate student, visiting the trials and having lunch with David on the porch at Doylestown, Pa. I remember his many visits to Pennsylvania State University. I remember projecting his slides during one of his presentations. I remember his kind letter to me after I indicated that I was unable to begin an internship in Santa Paula, Calif. What a giant!

I have been fortunate to

Fig.. 7. Donald Egolf. and industry leaders. Orlando Pride of Butler, Pa., bred both azaleas and the 'Grace Hybrids' of American hollies. Richard Jaynes was responsible for the great advances in Kalmia (mountain laurel). Donald Egolf (Fig. 7), of the National Arboretum, set the standard of excellence in the breeding of ornamental plants.

I feel a special kinship to those scientists who have shared my love of Pelargonium, I note the special friendship of James Tammen, the person who inspired me to devote my life to this beautiful plant. Wolfgang Horn of the Technical University of Munich

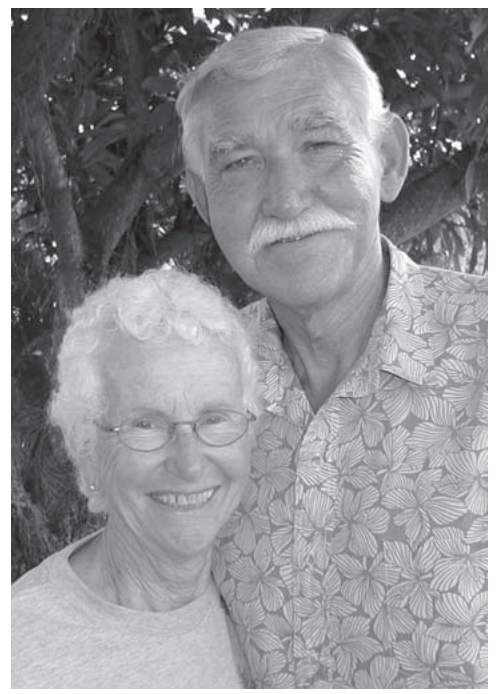

Fig. 8. Jane and Glenn Goldsmith. Photo courtesy of Goldsmith's Seeds. made a real difference in unraveling the genetic and cytological secrets of this genus. Adri van der Walt, the superb taxonomist from South Africa, is the ultimate source of information on the systematics of Pelargonium.

It is rare when an outsider has an opportunity to view the beginning of what eventually becomes a world-class enterprise. I remember being with Elmer Twedt (Ferry-Morse in San Jaun Bautista, Calif.) in 1962 when he visited a fledging seed operation. It was the first year for Glenn and Jane Goldsmith (Fig. 8). I was impressed by what I experienced, not the farm or even the plants or even the breeder although Glenn was an impressive young man. What had a profound effect was that an employee of one company was helping a new business germinate. This camaraderie is perhaps not as prevalent today in our conglomerate world but it is the reason why our industry has been successful in "creating a more beautiful world."

\section{Literature Cited}

Anonymous. 1976. Breeding plants for home and garden-A handbook. Plants and Gardens 30(1)

Anonymous. 2002. Report of the herbaceous ornamental crop germplasm committee. http:www.ars-grin.gov/npgs/cgc_/reports/herbscgc.

Ascher, P.D. 1976. Self-incompatibility systems in floricultural crops. Acta Hort. 63:205-215.

Asen, S. and R. Griesbach. 1983. High pressure liquid chromatographic analysis of flavonoids in geranium florets as an adjunct for cultivar identification. J. Amer. Soc. Hort. Sci. 108(5):845-850

Bamford, R. and F.B. Winkler. 1941. A spontaneous tetraploid snapdragon. J. Hered. $8: 242,278$

Bateson, W. and R.P. Gregory. 1905. On the inheritance of heterostylism in Primula. Roy. Soc. Proc. Ser. B. 76:581-586.

Bateson, W., E.R. Saunders, and R.C. Punnett. 1905. Sweet pea. (Lathyrus odoratus) Roy. Soc. [London] Evolution Com. Rpts. 2:80-99.

Baur, E. 1918. Mutationen von Antirrhinum majus. Vorlaufige Mitteilung Ztschr. Induktive Abstam. u. Vererbungslehre 19:177-193.

Babcock, E.B. and R.E. Clausen. 1927. Genetics in relation to agriculture. 2nd ed. New York.

Benary, R.E. 1993. 150 Years of creative plant breeding with Ernst Benary. Hann, Muenden.

Blakeslee, A.F. and A.G. Avery. 1937. Methods of inducing chromosome doubling in plants. J. Hered. 28:393-411.

Bodger, H. 1961. The commercial production of seeds of flowers, p. 216-220. In: Seeds. The yearbook of agriculture. U.S. Dept. Agr., Wash., D.C

Boswell. V.R. 1961. Introducing new horticultural varieties, p. 382-393. In: Seeds The yearbook of agriculture. U.S. Dept. Agr., Wash., D.C.

Boyle, T.H. and D. Stimart. 1982. Interspecific hybrids of Zinnia elegans Jacq and Zinnia angustifolia HBK. Embryology, morphology and powdery mildew resistance. Euphytica 31:857-867.

Brewbaker, J.L. 1959. Biology of the angiosperm pollen grain. Indian J. Genet. Plant Breed. 19(2):121-133.

Callaway, D.J. and M.B. Callaway. 2000. Breeding ornamental plants. Timber Press, Portland, Ore.

Carter, W.B. and E.P. Bugbee, Jr. 1961. How we get seeds of vegetables and flowers, p. 493-499. In: Seeds. The yearbook of agriculture. U.S. Dept. Agr., Wash., D.C. 
Clark, D.G. 1996. Plant biotechnology: How it is affecting floriculture. Seed World. 134(12):12-13.

Cook, R.C. 1936. A haploid 'Marglobe' tomato, practical application of a 'short cut' for making a pure line. J. Hered. 27:433-435.

Cook, R. 1937. A chronology of genetics, p. 1457-1477. In: USDA yearbook. U.S. Dept. Agr., Wash., D.C.

Correns, C.F.J.E. 1900. G. Mendels Regel uber das verhalten der Nachkommenschaft der Rassen-Bastarde. Ber. Deut. Bot. Gesell. 18:158-168.

Correns, C.F.J.E. 1900. Gregor Mendels Versuche uber Pflanzenhybriden und die bestatigung ihrer Ergebnisse durch die Neuesten Untersuchungen. Bot. Ztg. (II) $58: 230-235$.

Craig, R. 1994. Breeding improved cultivars, p 407-424. In: E.J. Holcomb (ed.). Bedding plants. vol. 4. . Ball Publ., Batavia.

Craig, R. and L. Laughner. 1985. Breeding new cultivars, p. 526-539. In: J.W. Mastalerz and E.J. Holcomb (eds.). Bedding plants III. Pa. Flower Growers.

Craig, R., J.I. Medford, R.O. Mumma, D. Cox-Foster, and D. Schultz. 1999. 49 14: 0-ACP Fatty Acid Desaturase and Gene Therefor. U.S. Patent \#5,856,157.

Craig, R., K. Nichols, and B. Gatzke. 1979. Evaluation of culture-virus-indexed geraniums. HortScience 14:470.

Craig, R. and J.R. Oglevee. 1990. Precision Flowering of Regal Pelargoniums (Pelargonium $\times$ domesticum). U.S. Patent $\# 4,897,957$.

Crane, M.B. and W.J.C. Lawrence. 1938. The genetics of garden plants2nd ed. MacMillan and Co., Ltd., London.

Darwin, C.R. 1859. On the origin of species by means of natural selection, or the preservation of favoured races in the struggle for life. London.

de Nettancourt, D. 2001. Incompatibility and incongruity in wild and cultivated plants. Springer-Verlag, Berlin-Heidelberg.

Dermen, H. 1960. Nature of plant sports. Amer. Hort. Mag. 39:123-173.

Deroles, S.C., M.R. Boase, C.E. Lee, and T.A. Peters. 2002. Gene transfer to plants, p. 155-196. In: Breeding for ornamentals: Classical and molecular approaches. Kluwer Academic Publishers, Dordrecht.

de Vries. H. 1900. Sur la loi de disjonction des hybrides. Compt. Rend. Acad. Sci. (Paris) 130:845-847.

Digby, L. 1912. The cytology of Primula kewensis and of other related Primula hybrids. Ann. Bot. [London] 26:357-388.

Dudareva, N. 2002. Molecular control of floral fragrance, p. 295-310. In: Breeding for ornamentals: Classical and molecular approaches. Kluwer Academic Publishers, Dordrecht.

East, E.M. 1915. An interpretation of self-sterility. Natl. Acad. Sci. Proc. 1:95-100.

Emsweller, S.L. 1941. Induced polyploidy in floriculture. Amer. Naturalist 75 310-326.

Emsweller, S.L., P. Brierley, D.V. Lumsden, and F.L. Mulford. 1937. Improvement of flowers by breeding, p. 890-998. In: USDA yearbook (bibliography separate, p. $1-31)$.

Evans, D. 1989. Techniques in plant cell and tissue culture, p. 53-76. In: S-d Kung and C. Arntzen (eds.). Plant biotechnology. Butterworth, Boston.

Ewart, L.C. 1981. Utilization of flower germplasm. HortScience 16(2):135-138.

Griesbach, R.J. 1988. Recent advances in the protoplast biology of flower crops. Scientia Hort. 37:247-256.

Griesbach, R.J. and S.M. Berberich. The early history of research on ornamental plants at the U.S. Department of Agriculture from 1862-1940. HortScience 30(3):421-425.

Hadi, M. and M. Bridgen. 1996. Somaclonal variation as a tool to develop pest resistant plants of Torenia fournieri 'Compacta Blue.' Plant, Cell, Tissue Organ Cult. 46:43-50.

Harbaugh, B.K. and J.W. Scott. 1996. 'Maurine Blue' Lisianthus (Eustoma grandiflora (Raf.) Shinn.) HortScience 31(6):1055-1056.

Hurst, C.C. 1905. Mendelian characters in plants and animals. Rpt. 3rd Intl. Conf. Genet. (R.H.S.) p. 114-129.

Iltis, H. 1932. The life of Mendel. Unwin Brothers Ltd., Woking, U.K. (original version published in German in 1924 by Julius Springer, Berlin.)

Kemper, S. 1994. He "wrestles" wild plants until they release his dreams. Smithsonian (Aug.):82-90.

Klein, T. M.,E.D. Wolf, R. Wu, and J.C. Sanford.1987. High velocity microprojectiles for delivering nucleic acids into living cells. Nature 327:70-73.

Larson, R. 1992. Introduction to fkoriculture. 2nd ed. Academic Press.

Laughner, L. 1985. Breeding and evaluation of Pelargonium for resistance to geranium rust, Puccinia pelargonii-zonalis Doidge. MS thesis. Pa. State Univ.

Lee, H., S. Huang, and T. Kao. 1994. S proteins control rejection of incompatible pollen in Petunia inflata. Nature 367:560-563.

Legro, R. A. H. 1961. Species hybrids in Delphinium. Euphytica 10:1-23.

Lemon, D. 2003. Personal communication.
Marcotrigiano, M. 1997. Genetic mosaics and plant improvement. Plant Breeding Rev. 15:43-84

Marsolais, A.A., D.P.M. Wilson, and J. Tsujita. 1991. Somatic embryogenisis and artificial seed production in zonal (Pelargonium $\times$ hortorum) and regal (Pelargonium $\times$ domesticum) geraniums. Can. J. Bot. 60:1188-1193.

Martinez, R.A. 1997. The master of seeds: Life and work of Claude Hope. Burpee Books.

Mendel, G.J. 1866. Versuche uber Pflanzen-hybriden. Verhandl. Naturf. Ver. Brunn 4 (Abhand1.):3-47.

Mol, J., A. Stuitje, A. Gerats, A. van der Krol, and R. Jorgensen. 1989. Saying it with genes: Molecular flower breeding. TIBTECH 7 (6):148-153.

Morgan, T.H., A.H. Sturtevant, H.J. Muller, and C.B. Bridges. 1915. The mechanism of Mendelian heredity. New York.

Murashige, T. 1974. Plant propagation in tissue culture. Annu. Rev. Plant Physiol. 25:135-166.

Nau, J. 2000. Personal communication.

Olby, R.C. 2000. Horticulture: The font for the baptism of genetics. Nature Rev. $1: 65-70$.

Onofrey, D. 1999. History of U.S. floriculture. Greenhouse Grower Mag. (Fall) Meister Publ. Co. Willoughby, Ohio.

Palmer, J.D., J.M. Nugent, and L.A. Herbon. 1987. Unusual structure of geranium chloroplast DNA: A triple sized inverted repeat, extensive gene duplications, multiple inversions and two repeat families. Proc. Natl. Acad. Sci. USA 84(3): 769-773.

Paris. C.D., W.J. Haney, and G.B. Wilson. 1960. A survey of the interactions of genes for flower color. Mich. State Univ. Tech. Bul. 281

Pelczar, R. 2000. Breeding plants for the future. Amer. Gardener 79 (5):18-25.

Power, J.B., S. Berry, E. Freason, and E.C. Cocking. 1977. Selection of procedures for the production of interspecies somatic hybrids of Petunia hybrida and $P$. parodii. Plant Sci. Lett.10:1-6.

Power, J.B., S.E. Cummins, and E.C. Cocking. 1970. Fusion of isolated plant protoplasts. Nature 225:1016-1018.

Ricker, P.L. 1961. The seeds of wildflowers, p. 288-294. In: Seeds. The yearbook of agriculture. U.S. Dept. Agr., Wash., D.C.

Roberts, H.F. 1929. Plant hybridization before Mendel. Princeton, N.J.

Ruttle, M.L. and B.R. Nebel. 1939. Cytogenetic results with colchicine. Biol. Zentral. 59:79-87.

Sagawa, Y. and G.A.L. Mehlquist. 1957. The mechanism responsible for some x-ray induced changes in flower color of the carnation, Dianthus caryophyllus. Amer. J. Bot. 44(5):397-403.

Scott, E.L. 1957.The breeders handbook. Natl. Chrysanthemum Soc., Bogota, N.J. Skirvin, R.M. and J. Janick. 1976. Tissue culture-induced variation in scented Pelargonium spp. J. Amer. Soc. Hort. Sci. 101(3):281-290.

Sink, K.C. and J.B. Power. 1977. The isolation, culture and regeneration of leaf protoplasts of Petunia parviflora. Plant Sci. Lett. 10:335-340.

Stuart, W. 1912. Mendelian inheritance in the carnation. Vt. Agr. Expt. Sta. Bul. 163.

Sparnaajji, L.D. 1979. Polyploidy in flower breeding. HortScience 14(4):496-499.

Stewart, R.N. and T. Arisumi. 1966. Genetic and histogenic determination of pink bract color in poinsettia. J. Hered. 57:217-220.

Tackholm, G. 1920. On the cytology of the genus Rosa. Svensk. Bot. Tidskr. 14: $300-311$

Tilney-Bassett, R.A.E. 1963. Genetics and plastid physiology in Pelargonium. Heredity 18(4): 485-504.

Tschermak, von Seyeenegg, E. 1900. Uber Kuntsliche Kruezung bei Pisum sativum. Ztschr. Landw. Versuchsw. Osterr. 3:465-555.

Vainstein, A. 2002. Breeding for ornamentals: Classical and molecular approaches. Kluwer Academic Publishers, Dordrecht.

Viehmeyer, G. 1955. Chrysanthemum improvement. N. Platte (Neb.) Expt. Sta. Bul. 43.

Warner, M.F., M.A. Sherman, and E.M. Colvin. 1934. A bibliography of plant genetics. USDA Misc. Publ. 164

Watson, J.D. and F.H.C. Crick. 1953. A structure for deoxyribose nucleic acid. Nature 171:737.

Watts, L. 1980. Flower and vegetable plant breeding. Grower Books, London.

Wilkins, H.F. and J.E. Erwin. 1998. Necessary considerations to introduce a new taxon. In: J.A. Considine and J. Gibbs (eds.). Proc. 3rd Symp. New Floricultural Crops. Acta Hort. 454:81-83.

Winkler, H. 1916. Uber die experimentelle Erzuegung von Pflanzen mit abweichenden Chromosomenzahlen. Ztschr. Bot. 8:417-531.

Winters, H.F. 1973. Impatiens from New Guinea. Amer. Hort. 52(3):16-22

Zirkle, C. 1935. The beginnings of plant hybridization. Philadelphia. 